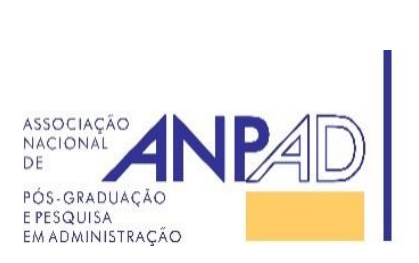
Available online at
http://www.anpad.org.br/bar
BAR, Rio de Janeiro, RJ, Brazil, v. 15, n. 3, art. 1, e180026, 2018

\title{
Sharing Economy and Sustainability Logic: Analyzing the Use of Shared Bikes
}

\author{
Suzenny T. Rechene ${ }^{1}$ \\ Minelle E. Silva ${ }^{2}$
}

Simone A. P. Campos ${ }^{3}$

Instituto Federal de Educação, Ciência e Tecnologia do Pará, Marabá, PA, Brazil ${ }^{1}$

Universidade de Fortaleza, Fortaleza, CE, Brazil ${ }^{2}$ Universidade Federal de Santa Maria, Santa Maria, RS, Brazil ${ }^{3}$

Received 25 February 2018; received in revised form 22 June 2018; accepted 6 July 2018; first published online 14 August 2018.

Editor's note. Márcia Dutra Barcellos served as Action Editor for this article. 


\begin{abstract}
A sustainability-oriented logic is required in order to change the consumerist logic of the society. This is possible by changing the beliefs and values shared among stakeholders regarding their behaviors. The institutional logic of sustainability (ILS) concept emerges in response to this need. In the context of the sharing economy, this research aims to understand the formation of ILS with the implementation of shared bikes in the city of Fortaleza-CE. Therefore, an in-depth case study was developed with actors that developed the Bicicletar project. The results demonstrate that: (a) several events happened to enable the insertion of the project; (b) city hall played a prominent role as a stimulator of change; (c) the city's mobility structure has been modified; and (d) sustainability practices are observed in all dimensions, with an emphasis on the environmental one. With this discussion, we contribute to the understanding of how sustainability can be practiced in other contexts. There is also the contribution of theoretical elements that facilitate understanding of the sustainability concept.
\end{abstract}

Key words: sustainability; institutional logic; sharing economy; Bicicletar project. 


\section{Introduction}

The complexities involved in the sustainability construct have been developing over the years (Claro, Claro, \& Amâncio, 2008). To be sustainable, from the entrepreneurial to the individual context, new behaviors and perceptions are required in order to address one of the main challenges of sustainable actions: the construction of a logic capable of institutionalizing these actions in organizations (Munk, Souza, \& Zagui, 2012). The incorporation of new practices in this change of logic has given a new meaning to the context of development in society. Hence, new practices create variations of problem solving (Souza-Silva \& Davel, 2007). In this way, the logic of capital accumulation and our way of using nature gives way to a new set of values for society, focusing on respect for the environment and on alternative development, which become important aspects to be considered in the market.

Therefore, the possibility of change "as an alteration of standards and rules to ensure conformity and reduce risks and uncertainties" (Carvalho, Andrade, \& Mariz, 2005, p. 3) in institutional theory advances towards a sense of sharing organization, recognition that the actors involved will solve problems and make decisions based on a list of alternatives available in the current institutional logic (IL) (Lounsbury, 2007). Considering that different logics may exist in society, among which sustainability may be a focus, Silva and Figueiredo (2017) propose the institutional logic of sustainability (ILS). ILS can highlight a debate about how sustainability can be observed and practiced as a result of socially constructed actions and intentions (Silva \& Figueiredo, 2017).

Regarding practice, according to Cavalcante and Bispo (2014), one must understand that "it goes beyond the notion of routine, individual action or simply doing a certain activity" (p. 7). It is a socially sustained action that enables conceivable social order (Gherardi, 2013). Thus, sustainability understood as a practice is "a phenomenon that occurs in the daily routine, in a particular and situated way, involving human and nonhuman elements that mutually influence each other in the conception of the organization" (Cavalcante \& Bispo, 2014, p. 9). This perspective contributes to the understanding of the institutional logic and the practical identification of how sustainability can be understood as a verb, with a linked action, and not a noun (Silva \& Figueiredo, 2017).

In this process of change and adaptation to a new social context, Barbieri, Vasconcelos, Andreassi and Vasconcelos (2010) emphasize that organizations have looked at innovation as a way to meet the three sustainability dimensions, and that this fact has institutionalized a new production logic based on sustainability. From this point of view, Gansky (2011) argues that resource reduction and increased urban density have forced traditional business models to find new practices in the use of technology and social networks. In light of this, collaborative market systems, including sharing economy (SE), have emerged as important alternatives to the capitalist format and can be paths that lead to sustainability (Heinrichs, 2013; Rifkin, 2016).

Sharing Economy has used market intelligence to promote a more collaborative and sustainable society (Frenken \& Schor, 2017; Heinrichs, 2013). In this context, within the conceptual apparatus of organizational institutionalization (DiMaggio \& Powell, 1983), the concept of IL is a prolific field for the understanding of the meanings attributed by society to these practices within the sharing economy. Martin (2015) mention the relation of SE with a new IL and a fertile field within a socio-technical transition. There are several contexts that can be studied following this vision. Within the framework of SE, sharing vehicles appears as a prominent example towards sustainability (Heinrichs, 2013; Martin, 2016).

Thus, the implementation of shared bikes, the first sharing vehicle model in the city of Fortaleza$\mathrm{CE}$, is proposed to open the discussion about the formation of ILS, with the case of the Bicicletar Project, the object of this study. The project briefing presents itself as a "sustainability project" (Bicicletar, 2014, our translation), which is relevant to stimulate a debate around sustainability logic. Here, the shared bikes represent SE and contribute to sustainable mobility, following the station-based model (Vaskelainen \& Münzel, in press). Therefore, the objective of this research is to understand the formation of ILS from the implementation of shared bikes in the city of Fortaleza-CE, Brazil. 
This research is justified by the use of an emerging theoretical discussion that looks, through its dimensions (event sequencing, institutional entrepreneurship, structure overlap, and sustainability practice), to understand ways in which it will be possible to incorporate sustainability in different contexts. The research seeks to contribute to a greater consistency in the construction of theory related to sustainability, as well as to facilitate the understanding of the sharing economy as an economic system that can contribute to sustainability. To better understand the research, in addition to this introduction, discussions presented below will enable the identification of the research conclusions.

\section{Theoretical Framework}

This section presents the main elements that guided the research. For this, sustainability is understood as a solution to different environmental problems that affect both the economic and social issues of human life (Iyer-Raniga \& Treloar, 2000).

\section{The institutional logic of sustainability}

Faced with the constant changes and uncertainties imbued with issues involving sustainability, the institutional perspective has proved to have a favorable theoretical approach for its understanding. With a movement that started in the 1970s, the institutional prism had economists and sociologists as precursors that deepened and solidified its theory (Carvalho, Vieira, \& Lopes, 1999). For Guarido, Machado-da-Silva and Gonçalves (2009), this is one approach to study one of the most prolific organizations. Thus, from the IL conception, the necessary contribution was found to support the selected perspective of the formation of a logic related to sustainability (Silva \& Figueiredo, 2017).

The institutional perspective allows the recognition of different rationalities in the organizational space, and to consider sharing values in the environment as an object of organizational analysis, providing answers that traditional approaches don't allow (Carvalho et al., 1999). Thus, IL is an approach that considers both the material and the symbolic in its analysis and is an approach that seeks to understand how cultural aspects influence organizational change (Thornton \& Ocasio, 1999). The change process in organizations results in a logic based on the legitimacy given to the same set of structures and symbols by different actors.

From this perspective, it is necessary to consider that logic is understood by the ancient philosophers as an instrument that observes the way in which a reasoning was constituted, providing knowledge of something from another (Chauí, 2010). Thus, the construction of an IL occurs through a socially constructed identity that generates meaning to its reality (Thornton \& Ocasio, 2008). For Friedland and Alford (1991) and Thornton (2002), segments of society such as family, state, and corporations, amongst others, provide a varied set of logics, responsible for conflicts or institutional conformities, if we consider that these logics may diverge or complement each other.

Thus, IL can be understood as a meta-theory, capable of integrating the individual, organizational and institutional levels (Thornton, Ocasio, \& Lounsbury, 2012). In this sense, institutional logics are comprised of frames of reference or sets of material practices and symbolic constructions that constitute the organizational principles of an institutional order (Friedland \& Alford, 1991), being defined by Thornton and Ocasio (1999, p. 804) as "historical patterns of material practices, assumptions, values, beliefs, and rules, socially constructed". Such a view helps individuals (a) to produce and reproduce their subsistence materials, (b) organize time and space, and (c) generate meaning for their social reality.

By considering this perspective, the practice is considered one of the central elements responsible for institutionalization in organizations (Meyer \& Rowan, 1977), since it is situated in their historical, social and cultural contexts (Nicolini, Gherardi, \& Yanow, 2003). However, there is a concern about the loss of critical power when practice is considered as only what people do, restricting their meaning to the routine (Gherardi, 2013). It should be pointed out that the conception adopted in this paper is that 
"practices are not only recurrent patterns of action (level of production) but also recurrent patterns of socially sustained action (production and reproduction)" (Gherardi, 2013, pp. 108-109).

In order to conceive IL, it is necessary to consider important characteristics that are pointed out as central to its formation. This formation is understood as the action of constituting a whole from parts, or promoting a corpus by means of its attributes. In this way, characteristics considered essential for the formation of IL are: the economic system, sources of identity, sources of legitimacy, sources of authority, bases of mission, bases of attention, bases of strategy, institutional governance, institutional entrepreneurship, event sequencing, and structure overlap (Thorton \& Ocasio, 2008).

These characteristics are accepted by Silva and Figueiredo (2017) as the basis for the design of the ILS. However, these authors postulate that to discuss this construct, it is possible to examine only three of these characteristics: institutional entrepreneurship, structure overlap and event sequencing. In addition, so as to understand the institutional logic in the context of sustainability, the authors include the dimension of sustainability practice as an analytical support necessary in the construction of an ILS. Each of the dimensions needs to be understood and assumed as mutually connected, since from the moment one undergoes change, the others can be affected and an overlapping of changes may happen.

In this sense, institutional entrepreneurs understand the individuals or groups that can stimulate new avenues in a sector to introduce new practices that were not previously considered (Thornton, Jones, \& Kury, 2005). Institutional entrepreneurs (IE) guide the process of change, either from a starting point or in the midst of the changes, and play a fundamental role in the development of an institutional logic, in this case the ILS. While organizations are acting in response to pressures for sustainable development, emerging actors or stakeholder groups that embody sustainability practices can be viewed as IEs. They should not be viewed as heroes or saviors, but as agents of change (Cruz, 2016).

In addition, Silva and Figueiredo (2017) affirm that the structure overlap is related to the change of individual rules and organizational structures, in which the actors, even if they are of different cultures, are forced to work together to promote a change of IL (Kanter, 2011). This characteristic, pointed out as an element of analysis presented below, includes the necessary understanding of the issues related to the formal and informal structure that surround the field. Event sequencing is also conceived in the ILS construct, since it produces new events and strengthens the logic formed (Thornton et al., 2005). This logic formation occurs through a set of events, which need to be linked together and have mutual influences and relationships. In addition, the sequence of events allows us to analyze the flow of power, practices and routines for the IL in a given time frame.

Considering sustainability as a set of practices that guide companies on the road to new institutional formatting, sustainability practices are shaped and consolidated due to the need to respond to pressures from society, government and competition. Thus, sustainability integrates the field of IL, based on its recognition as a daily socio-material practice that is not prescriptive, which arises, perpetuates and modifies itself in the daily interactions between human and nonhuman (Cavalcante \& Bispo, 2014). In this way, sustainability emerges and resurges, recursively, as a result of the actions and intentions socially constructed by social agents (Silva \& Figueiredo, 2017).

Into the emergence of an ILS, the flows are influenced by time, through event sequencing. This can generate a change of structure when influenced by new IE practices and actions, and is not limited only to the material, but also considers the meanings that can be shared by the actors. Thus, the ILS is defined as:

The outcome of actions - developed and institutionalised by organisations - that improve the sustainability of a given organisational field. The practice of sustainability emerges in the context of actions within institutional structures that were created to improve sustainability. The ILS emerges as both the cause and consequence of the practice of sustainability; it enables new agent practices, new structures or structural changes and new organisational actions that further support it (Silva \& Figueiredo, 2017, p. 8). 
Therefore, when considering sustainability as a socio-material practice, it is possible to understand the world as a result of human and nonhuman actions and interactions. This represents an advance regarding how to implement sustainability values in society. According to Vaskelainen and Münzel (in press), ILs empower actors to develop business models aligned with their principles. Following this point of view, using sustainability as practice can support the emergence of new business models, such as those based on sharing economy characteristics.

\section{Sharing economy}

The SE has proved to have been favorable in achieving sustainability goals, especially in large cities (Chase, 2015; Gansky, 2011). This is because the use of a socioeconomic model that values sharing to the detriment of obtaining generates a change of behaviors in society and in the market. SE is rapidly growing and many actors are interested in its nature and impact, including entrepreneurs, innovators, policy-makers, academics and the public (Frenken \& Schor, 2017; Martin, 2015). Although there are confusions about expressions related to SE, the complementary existence with collaborative consumption as pathways to sustainability is clear (Petrini, Freitas, \& Silveira, 2017).

Some of the key points of this assertion is that SE can address critical sustainability issues such as uncontrolled consumption (Botsman \& Rogers, 2011), degradation of nature (Gansky, 2011) and increased urban mobility (Chase, 2015; Cohen \& Kietzman, 2014). Using the argument that there are requirements for changes, we adopt the debate from Heinrichs (2013), which considers sharing economy as one of the main routes towards achieving sustainability. In addition, it is possible to highlight the SE as a niche that can support socio-technical transition (Martin, 2015); however, there are complex discourses and contradictory frames that require more understanding (Martin, 2016).

A powerful trend of collaborative SE business proliferation may threaten the traditional market form, as this has proven to be efficient in relation to pressures on changing customer values and reduced resources (Gansky, 2011). The need to create different production relations converges with the proposal of the eminence of "a new mode of production superior to capitalism" (Freitas, Nélsis, \& Nunes, 2012, p. 47). Rifkin (2016) states that "capitalism is giving birth to an offspring" (p. 13), called the Sharing Economy or Collaborative Economy. This panorama involving a new role of consumers and organizations, new market formats, technology and motivations for new socioeconomic relationships has demonstrated the emergence of collaborative consumer systems (Belk, 2010; Botsman \& Rogers, 2011; Chase, 2015; Gansky, 2011; Ornellas, 2013).

A collaborative consumer system that is part of the SE can be defined as the possibility for a new market format, based on the use of digital technology, which intends to make the economy circulate from the already discarded resources of nature and existing products, taking into consideration the new values of customers, the regeneration of natural resources and the planet's capacity to absorb humanity's waste, making goods more accessible to those who cannot or do not want to own them (Botsman \& Rogers, 2011). According to Frenken and Schor (2017, p. 6), "the alleged sustainability benefits of the sharing economy are, however, much more complex than initially assumed".

For Rifkin (2016), the younger generation is in search of a marginal cost close to zero. That is, with the internet and ever stronger networks, people are sharing not only the automobile, the main status symbol of the capitalist system, but also houses, clothes, toys, tools and even skills. What was once a consequence of market policies, has in this new consumer behavior paradigm become one of the main parameters for changes in how the economy has been developing. There are high level of complexity related to sustainability, which means the triple bottom line (Elkington, 2002), impacting SE benefits (Frenken \& Schor, 2017). In this way, "there is also considerable interest in the sharing economy as a means of promoting sustainable consumption practices" (Martin, 2016, p. 3).

This study therefore intends not only to support the understanding of the sustainability theme in organizations, but also to help solve their practical problems, investigating the implementation of sustainability as a daily practice by SE users by specifically looking at the project of shared bikes. This is supported by Martin (2016, p. 149) since SE "is framed as: (a) an economic opportunity; (b) a more 
sustainable form of consumption; (c) a pathway to a decentralised, equitable and sustainable economy; (d) creating unregulated marketplaces; (e) reinforcing the neoliberal paradigm; and (f) an incoherent field of innovation".

The representativeness of the research will be supported with empirical data on the problems of SE, pointed out by Silveira, Petrini and Santos (2016), such as: understanding of the different actors' roles and motivations, mainly identifying the directors related to values, beliefs and feelings and types of technologies that support the sharing economy. Also, using the exchange between the public and private sectors in the SE as an object, as by Cohen and Kietzman (2014), is a big opportunity gap for research. Hence, there is potential contribution for understanding SE, focused here in bike sharing, as a trigger to promote the emergence of an ILS.

\section{Research Method}

For this study, we used qualitative research to understand the social and human activities based on reflection of perceptions (Collis \& Hussey, 2005). In addition, according to Silveira et al. (2016), qualitative research becomes appropriate for SE due to the fact that the debates on the subject are still not very robust. To achieve this, we chose a case study as a research strategy to more deeply investigate a contemporary phenomenon in its real world context (Yin, 2014). This strategy is used since it is intended to "focus on practical problems arising from the intricate individual and social situations present in activities, procedures and daily interactions" (Godoy, 2006, p. 121). This vision is based on the understanding of how organizations practice sustainability.

The case studied in this research is called the Bicicletar project, a system of bike sharing in the city of Fortaleza, Ceará, in northern Brazil. This case was chosen due to the great expansion in the use of bike sharing in Brazil, also one of the most prominent examples of SE. The Bicicletar Project was implemented by the municipal government of Fortaleza in December 2014, through an agreement between the public and private sectors (Sistema de bicicletas compartilhadas de Fortaleza, 2014). The project is defined as a "sustainability project" in which sharing bicycles offer a sustainable and nonpolluting transportation option (Bicicletar, 2014, our translation).

Considering the arguments of Yin (2014), we used as sources of evidence: secondary data, interviews and non-participant observations. Thus, the data collection phase of the research had three steps. As an initial step, a desk research of documents was conducted in October 2016 through Internet searches using the Google search tool and public sector data platforms to gather the preliminary information that underpinned the initial phase of data collection, using the keywords: bike sharing Fortaleza, and then cycling. The documents selected and analyzed at this stage were: the Bicicletar project website, sponsoring company website, website of the operating company, and websites of Fortaleza news portals.

The second stage of data collection was achieved through semi-structured interviews, aiming at finding out the reflections of the subjects themselves about the reality that they experience (Minayo, 2011). According to Silveira et al. (2016), the individual, as well as the organization, is identified as the object of analysis in the theme of the SE, considering that they have "directors related to values, feelings and human beliefs as vectors to embrace the SE" (p. 6). Interviews were conducted between November 2016 and January 2017 with the two groups of subjects. First were three in-depth interviews with a representative from city hall, a representative from the sponsoring company and a representative from the operating company. These interviewees were coded as E1, E2 and E3, respectively.

In the second group, 15 interviews were conducted with users at three Bicicletar bike stations. The selection of these sites followed two criteria: (a) the first two in a region on the outskirts of Fortaleza - Aterro and Aterrinho, and (b) the most used by neighborhoods located near the Benfica Shopping mall in the district of the same name. As a way to better streamline the research, five people were interviewed 
per station, according to accessibility. The interviews were audiotaped with permission from the interviewees for later transcription. Users were identified as C1 to C15.

The third stage of data collection consisted of document research between February and May 2017, this time seeking new documents or documents that were mentioned during the interviews. The documents selected and analyzed in this stage were: Federal Law n 12587 of January 3, 2012 (Lei n. 12.587, 2012), Federal Law 10257 of July 10, 2001 (City Statute) (Lei n. 10.257, 2001), Fortaleza 2040 Plan (http://fortaleza2040.fortaleza.ce.gov.br/site/, retrieved July, 2016), Municipal Law n ${ }^{\circ} 10303$, of December 23, 2014 (Lei n. 10.303, 2014), Direct Integrated Cycle Plan (Plano Diretor Cicloviário Integrado [PDCI]), Bicicletar Project website, sponsoring company website, operating company website, news websites from the city of Fortaleza and the Fortaleza Mobility Plan (Plano de Mobilidade Urbana [PLANMOB]).

We opted for the content analysis suggested by Godoy (1995) for data analysis. Therefore, the dimensions related to ILS that can influence the insertion of SE were used as categories of analysis. These categories came from the literature and can support the comprehension on how bike sharing is related to sustainability logic. After being transcribed in full, the data obtained from the units of meanings were categorized as follows:

1. Institutional Entrepreneur: those responsible and the motivators for change, designing the internal incentives for this change.

2. Event Sequencing: the main events to encourage change, continuity and impact of the event(s), identification of the location of the event(s), creation of diagnoses or forecasts, and existence of external pressures and incentives.

3. Structure Overlap: adaptation to the use of technologies, infrastructure, acceptance, decisionmaking processes and definition of strategies.

4. Sustainability Practices: commitment, creation of routines and procedures, dissemination of sustainability, communication with stakeholders, social criteria for evaluating results, environmental criteria for evaluating results, economic criteria for evaluating results and actions practiced / defined as sustainable.

This information favors the recognition of the results and discussions that help to meet the objective and the identification of how the project in question may or may not be linked to the perspective of the institutional logic of sustainability.

\section{Findings and Data Analysis}

In order to analyze the formation of ILS in sharing vehicles, one of the modalities of a sharing economy, especially in shared bikes, it is necessary: (a) to understand training from the perspective of development of a logic from the context experienced (Gomes, 2005); and (b) to bring institutional theory closer to the practical issues of sustainability, not only to verify the existence of an ILS, but also to understand the process and stage of its formation. Thus, the following analysis investigates evidence of the formation process of an institutional logic of sustainability in the studied context.

\section{Constitution of the organizational field}

According to the secondary data, it can be stated that the organizational field of the Fortaleza Bicicletar Project, in the case of this study, was initially constituted of two different groups of actors. The first group is composed of three organizations: City Hall of Fortaleza, the sponsoring company and the operating company of the system, and the second group formed by users of the shared bikes. However, as claimed by Vaskelainen and Münzel (in press) the organizational field is not always stable 
since there are several institutional logics conflicting in the same context. Table 1 presents the roles of the actors who make up the shared bike field:

Table 1

Role of Organizational Actors

\begin{tabular}{lll}
\hline \multicolumn{1}{c}{ Actors } & \multicolumn{1}{c}{ Description } & \multicolumn{1}{c}{ Role in Bicicletar Project } \\
\hline City Hall (PAITT/SCSP) & $\begin{array}{l}\text { Municipal management } \\
\text { body }\end{array}$ & $\begin{array}{l}\text { Elaboration and development of the project. Also } \\
\text { responsible for monitoring and inspecting the system. }\end{array}$ \\
\hline Sponsoring Company & Medical cooperative & $\begin{array}{l}\text { Sponsorship to implement the project. Responsible } \\
\text { for funding the project. }\end{array}$ \\
\hline Operating Company & $\begin{array}{l}\text { Technology company } \\
\text { for urban mobility }\end{array}$ & $\begin{array}{l}\text { Development of the project together with the } \\
\text { appropriate sectors of the city hall. Operation of the } \\
\text { project system through one of its specialized } \\
\text { companies in sustainable transport. It is responsible } \\
\text { for the implementation, and development of all the } \\
\text { technological aspects, management and maintenance } \\
\text { of the project. }\end{array}$ \\
\hline
\end{tabular}

Note. Source: Research data.

Also included in the field are the users who have the role of consumers of shared bikes. According to data provided by the city hall, in its first month of implementation, in December 2014, the project recorded 10,639 trips made by consumers. As of December 2016, there were 50,283. This considerable increase in the number of uses contributes to the legitimacy of the project and to the process of social construction of an institutional logic (IL).

\section{Actions / evidence of sustainability}

There has been a tendency in Brazil to encourage bike sharing as an alternative for urban mobility and sustainability (BikePOA, BikeBH, BikeSampa, among others). In the case studied here, the project of shared bikes in Fortaleza is the Bicicletar. The incentive to include these alternatives for mobility has arisen due to a large number of federal, state and municipal laws and regulations that seek to encourage and prioritize the use of shared bikes in cities as a sustainable form of transportation.

The project started with 15 stations and 150 bikes in its implementation in December 2014 (Prefeitura de Fortaleza, 2014). In 2015 this rose to 40 stations and 400 bikes, and subsequently to 80 stations and 800 bikes in 2016. The goal according to the city hall is 300 stations by 2018 (Prefeitura de Fortaleza, 2015). In two years there was an increase of more than 500\% in the number of implanted bikes. This increase has shown that the project has been consolidating and that customers are increasingly using the shared bikes. By February 2017 the total number of trips made exceeded 1,400,000 (see http://www.bicicletar.com.br/, retrieved February 5, 2017). If all these trips had prevented the use of carbon-emitting vehicles, the $\mathrm{CO}_{2}$ credits would be about 519 tons, according to the City Hall Project coordinator.

Throughout the discussion, the character of urban mobility stood out. It has been perceived that there is a certain difficulty in delimiting which actions are related to the dimensions of sustainability; this fact can be accepted if we consider that the sustainability theme is very dynamic (Baumgartner, 2011). It should be noted, therefore, that the aspects related to urban mobility are closely linked to the three pillars of sustainability: environmental, social and economic, as shown in Table 2. 
Table 2

\section{Dimensions of Sustainability Expressed in the Quotes from the Actors}

\begin{tabular}{|c|c|c|c|}
\hline \multirow[t]{2}{*}{ Actors } & \multicolumn{3}{|l|}{ Related Dimensions } \\
\hline & Environmental & Social & Economic \\
\hline E1 & $\begin{array}{l}\text { "... but as we are part of the } \\
\text { mobility projects, it is not our } \\
\text { goal, but of course it will } \\
\text { decrease emissions." }\end{array}$ & $\begin{array}{l}\text { "... our goals are also very } \\
\text { focused to serve the entire city, } \\
\text { serve more regions, serve more } \\
\text { users, so when we talk about the } \\
\text { expansion of the system, we } \\
\text { think of the neighborhoods in } \\
\text { the surroundings regions that } \\
\text { have more people living in } \\
\text { them, there are more jobs being } \\
\text { offered ..." } \\
\text { "... I think there's almost } 80 \% \\
\text { accessing with the special pass." } \\
\text { "... but we are not focusing on } \\
\text { the issue of environmental } \\
\text { sustainability, but always } \\
\text { focusing on the issue of social } \\
\text { inclusion, the thansportation, } \\
\text { benefits for the people, how the } \\
\text { bicycle can improve the urban } \\
\text { environment, but this } \\
\text { environmental issue is a bonus." }\end{array}$ & $\begin{array}{l}\text { "... to ensure that people of all } \\
\text { classes can have access to this } \\
\text { system and that transportation is } \\
\text { good, a form of transport that is } \\
\text { cheap and feasible for everyone, } \\
\text { that they do not have to } \\
\text { compromise their monthly } \\
\text { budget to be transported in the } \\
\text { city." }\end{array}$ \\
\hline E2 & $\begin{array}{l}\text { "It's probably because the bike } \\
\text { helps to contain a little the race } \\
\text { there is for a car." }\end{array}$ & $\begin{array}{l}\text { "... it coincided that we were in } \\
\text { a moment of transition, ... with } \\
\text { the new management we began } \\
\text { to work with what we call } \\
\text { pillars, let's work on the } 4 \\
\text { pillars ... we will work with the } \\
\text { issues of physical activity, food, } \\
\text { socialness, relationships ..." }\end{array}$ & $\begin{array}{l}\text { "... help with the issue of } \\
\text { economic optimization, "Ah! I'll } \\
\text { save money with my } \\
\text { transportation, I'll ride my } \\
\text { bike." }\end{array}$ \\
\hline E3 & $\begin{array}{l}\text { "... but I know that for things } \\
\text { like batteries, equipment that we } \\
\text { cannot throw away just } \\
\text { anywhere, we work with } \\
\text { companies that recycle these } \\
\text { materials." }\end{array}$ & $\begin{array}{l}\text { "I've heard about users who } \\
\text { talked about quality of life, } \\
\text { whose lives have improved, } \\
\text { they are not stuck on the bus } \\
\text { anymore." }\end{array}$ & $\begin{array}{l}\text { "And this revenue diversity [of } \\
\text { the project] allows the user to } \\
\text { not pay too much for the bicycle } \\
\text { transportation system. Not even } \\
\text { the R } \$ 3.00 \text { or } R \$ 4.00 \text { he pays } \\
\text { for the bus ticket." }\end{array}$ \\
\hline
\end{tabular}

Note. Source: Research data.

It was identified that all the actors of the organizations involved had policies to promote sustainability before the implementation of the project, which indicates that sustainability was already being debated and developed. The interviewees from the organizations point out that the bike is sustainable in itself, according to the statements: "First, the bike is sustainability" (E3) and "the bike helps to contain a little the race there is for a car, this is already sustainable" (E2). When asked directly about sustainability practices in the project, there is a strong perception that sustainability has been achieved through shared bikes. Following is a quote that clearly demonstrates this perception:

[Bike] is a transport vehicle that does not emit a pollutant into the atmosphere, and neither a noise right? Static and space pollution is also lower than other transport vehicles. So it's a system that to me, biking equals sustainability. For example, it's been over a year now that we've developed a technique for setting up installations that is much faster and much more sustainable. It requires less material, which allows us to do less digging, and so is also a more sustainable process.... (E3). 
During interviews with users, some patterns of responses were identified in relation to the project understanding: C8 "Well, initially there is no burning of any kind of fuel, right? No oil is used, it is purely mechanical, so it does not emit any pollutants. It properly helps with sustainability". C6 "It allows people more access to transportation ... helps people create friendships with one another". C11 "Because it is sharing right. Buying a bike is expensive, rather expensive". C2 "It's very cool because there is no pollution in it". These quotes demonstrate the perception of users regarding bikes. According to the answers to the questions, the interviewees identified the positive impact of the project on the social, economic and environmental contexts, which for many should be intensified.

According to the data from the interviews with the actors of organizations and users, the impact of the project's results are related to sustainability. In direct relation to the economic pillar, the following were noted: lower cost with transportation, or even total elimination, allowing the user to invest in another benefit. In regard to the social question there is an increase in people's access to quality of life, which ranges from the physical to the psychological, by encouraging social relationships (formation of groups and approximation of communities), and greater care for the city.

For environmental issues, the results are more difficult to measure, but no less outstanding. The environmental benefits of using a non-polluting vehicle with no carbon dioxide emissions and the use of renewable energy were often expressed. These elements are prominent from the research outcomes; however, it is necessary to make clear that sustainability benefits of bike sharing can have more complexity (Frenken \& Schor, 2017), in addition to the elements presented here. Therefore, challenges always need to be observed to have sustainable mobility, which is broader than the insertion of SE. For instance, the lack of infrastructure in a city can create problems by using shared bikes.

\section{Formation of the institutional logic of sustainability}

For the theoretical discussion here presented and in order to understand the ILS formation, it is essential to analyze the dimensions necessary for the process of its organization, such as: institutional entrepreneurship, event sequencing, structure overlap and practice of sustainability. These four dimensions guarantee the foundation for the formation of ILS (Silva \& Figueiredo, 2017). As the institutional orders themselves can be changed (Vaskelainen \& Münzel, in press), if we consider the idea of the Institutional Entrepreneur, the municipal government of Fortaleza, sometimes personified in the figure of the mayor, has been recognized as such for stimulating change through their actions.

Thus, it can be observed that the institutional entrepreneur, represented by an institutionalized organization - city hall - responsible for structuring the project, may have strengthened the certainties around it and contributed to the formation of the ILS. As argued before, the IE is not a hero, but the one who can stimulate changes towards a new institutional logic. According to Martin (2016), policy-makers have a prominent role in the sustainability transition; hence since the city hall emerges as both trigger and supporter it is possible to clearly understand the contribution of IEs through sequencing events to ILS.

There were several events that enabled the project to be implemented and subsequently the search for sustainable mobility. We identified 16 events that occurred between 2012 and 2016. In general, in 2012 it is possible to observe two events that contributed to the beginning of the change, these were the sanctioning of a national legislation and a campaign proposal during the municipal elections. In 2013, a change in management of one of the actors meant they were directly inserted into the field. In the following years, 2014, 2015, and 2016, there were developments regarding standardization and expansion of actions. These events enable the understanding of how the organizational change process occurs and how the ILS is being disseminated, based on a time frame that analyzes the flow of power, practices and routines.

Considering an overview of the sequencing events, we highlight 2014 as the year with a greater number of events. This represented a growth in the number of social actors in the organizational field through new contracts and calls for projects covering different aspects of society. The sequence of events can influence the change of structure that comes with the insertion of sustainability practices and 
contribute to the formation of the ILS (Silva \& Figueiredo, 2017). With this notion, it is understood that a chain of events can be observed as promoters of actions that create a sense of sharing logic for the Bicicletar in Fortaleza.

The municipal elections, in the year 2012, started a sequence of events regarding the analysis of the sustainability logic according to sharing economy perspective. The events that have occurred were directly or indirectly influencing changes by including sustainability actions and practices, such as new positioning of the sponsor's brand as an indirect introduction. According to the sponsor's manager "we already have an internal support for races and walks, and [after the call for project] we start to think about the transport, because our city is very polluted; however, we did not think in a first moment 'let's think about its impact [the transport sector]', we just found an opportunity to change".

In the same way, PLANMOB emerged as a project that had an influence on the attitudes related to sustainability in urban mobility. According to the city hall project coordinator, the PLANMOB is a project create by the city hall to achieve the Fortaleza 2040 plan for a sustainable city. After implementing the project, changes started to happen in different aspects of mobility in Fortaleza, which demonstrates the impact of this event on the city (infra)structure. Based on this new project, several changes were introduced in the city, which contributes to the advance of a shared sustainability logic. Table 3 summarizes other events and structural changes regarding the creation of an ILS. This chain translates into a practice where new values and beliefs begin to be shared.

Table 3

Sample of Event Sequencing and Changes of Structure

\begin{tabular}{lll}
\hline \multicolumn{1}{c}{ Year } & \multicolumn{1}{c}{ Event } & \multicolumn{1}{c}{ Change } \\
\hline 2014 & Launch of Fortaleza 2040 plan & $\begin{array}{l}\text { Development of a project that define the target to achieve a } \\
\text { sustainable city. From this plan changes started to several } \\
\text { (infra)structures in the city, including mobility. }\end{array}$ \\
\cline { 2 - 3 } & $\begin{array}{l}\text { Call for companies interested in } \\
\text { sponsoring the project }\end{array}$ & $\begin{array}{l}\text { Publishing this call the city hall provided the start point } \\
\text { toward a public and private partnership focused on the } \\
\text { Fortaleza 2040 goals. }\end{array}$ \\
\hline 2015 & Bike path expansion program & $\begin{array}{l}\text { The change for a sustainable mobility plan requires more } \\
\text { bicycle paths through the city, which may facilitate the use } \\
\text { and adoption of sharing bakes. }\end{array}$ \\
\hline 2016 & $\begin{array}{l}\text { Urban planning into Fortaleza } \\
\text { 2040 plan }\end{array}$ & $\begin{array}{l}\text { Development of urban plan for the next 24 years toward the } \\
\text { sustainable city target. This plan is based on the societal } \\
\text { participation, which means a broad planning involving } \\
\text { several stakeholders. }\end{array}$ \\
\hline
\end{tabular}

Note. Source: Research data.

Table 3 demonstrate that the structural changes are not only related to the Bicicletar project, but that the mobility plan has influenced new local activities, which contributes to the creation of a sustainability logic. The sustainability practices, which are part of the ILS formation, are indicated by the recursiveness of practices in the transformation of the system (Ortner, 1984), which are observed in the use of sharing bicycles by indirect actions. The practice of replacing vehicles that emit pollutants with a non-emitting vehicle can have a great impact on environmental issues in the medium and long term, as can be observed in the following quote, from one of the representatives of the organizational actors.

"Because in Fortaleza, if I'm not mistaken, we have $61 \%$ of emissions which come from transportation, so this contributes $61 \%$ of greenhouse gas emissions, then both sharing bicycles integrated with electric cars and exclusive lanes, are all projects which think about this reduction”. (E1). 
However, it is understood that sustainability is linked, in addition to the environment, to at least two other pillars: social and economic. In this way, it is possible to verify that the use of the shared bikes of the Bicicletar project have met these requirements, allowing access to urban mobility (social) with low, or no cost to users, in an egalitarian way. It is noted in the analysis that there is a sharing of expressions directly linked to the object under study such as: transport and bicycle. There is also the identification of the institutional entrepreneur (i.e. city hall) and the field (Bicicletar). The emphasis on words such as: sustainability, environmental and people, and considering the need to share a vocabulary for appreciation ( $c f$. Gherardi, 2013), can infer that there is a communion of vocabulary among the actors, which reinforces the conception of the existence of a practice, and a focus on sustainability, which contributes to the formation of the ILS.

\section{Conclusions}

Based on the approach to the theme of sustainability and SE carried out by many authors (Chase, 2015; Gansky, 2011; Rifkin, 2016), a strong relationship was found between the two themes through the formation of an institutional logic of sustainability. Although the literature shows the contribution of SE to sustainability in its three dimensions (Botsman \& Rogers, 2011; Chase, 2015; Gansky, 2011; Rifkin, 2016), the research data pointed to a greater emphasis on the issue of the environment, in regard to aspects related to the improvement of the condition of the environment through the reduction of the emission of polluting gases. This fact can be justified, since the research field shows the exchange ratio of a polluting vehicle, the car, which uses fossil fuels, considered a great polluter and responsible for the greenhouse effect, with a non-polluting vehicle, the bicycle.

Following Vaskelainen and Münzel (in press), who found that it is not possible to identify the emergence of German carsharing without understanding the ILs, we found that sustainability can be considered the logic in the process of formation in the studied context. Although the project has only been implemented for two years, it has shown promise with each new season, bringing an increase in the number of bikes. In addition, we identified that the city has not limited itself to this project. Other projects are being planned for a more sustainable mobility, which demonstrates the quality of being able to change logic. It was evident in the dimensions - event sequencing, institutional entrepreneurship, structure overlap and sustainability practice, the existence of elements capable of understanding how they are building sharing beliefs, values and rules focused on sustainability based on the Bicicletar project.

The constant increase in the number of shared bikes offered strongly indicates the project's institutionalization. In order to verify the formation of the ILS, the existence of mechanisms of change in the IL was considered, and were thought to be sufficient for the verification of the ILS in the bike sharing project, namely: (a) sequence of events, understood as the main events that caused an impact on the change in the structure responsible for the ILS formation, in which 11 of the 16 identified had a high impact; (b) institutional entrepreneurship, identified as the City Hall of Fortaleza-CE, personified in the figure of the mayor, who played the role of stimulator of the changes and was able to reduce uncertainties during the changes; (c) structure overlap, illustrated through the changes that followed the municipal elections of 2012; and (d) sustainability practices, presented by the recursiveness of actions based on the sustainability pillars, such as the promotion of available low-cost urban transport with low environmental impact.

All these aspects are a guarantee of the formation of ILS. With this view it becomes clear that the theoretical-empirical debate presented demonstrates a degree of originality and novelty to converge the themes of SE and IL to focus on sustainability practice, which is still little explored. This is the theoretical contribution of this paper. Therefore, the role of the government as the institutional entrepreneur indicates to studies in SE the need to give more attention to this actor, clearly analyzing the institutional environment. Practical contributions are observed in two ways: (a) there is a comprehension about the ILS as a possible framework that can guide new strategies and change of 
elements around practices to create new logics; and (b) policy makers can have an overview about changes that emerge from their actions, which facilitate new decisions or support new changes. With these elements we contribute to both public and business administration.

The emphasis on only one of the mobility projects of the city of Fortaleza may be considered a limitation of this research, as well as the lack of interviews with more actors who integrate the organizational field of the project, which could have introduced more elements to enable the understanding of the practice of sustainability and how this is institutionalized as a logic. Therefore, it is necessary to highlight that the findings cannot be directly generalized to other contexts, since each institutional environment has its own specificities. However, this analysis can give support to comprehend other contexts and stimulate the development of new practices towards sustainability. We recommend that new research use the theoretical elements from this research in order to intensify theoretical aspects to better understand sustainability and, alongside this, more clearly understand what understanding should be given to this construct.

\section{Contributions}

1st author: Conceptualization and research design, data collection, analysis of results and article composition.

2nd author: Conceptualization and research design, including literature review, supervision, and composition review and editing.

3rd author: Conceptualization and methodological design of the research, providing contributions to the composition review and editing.

\section{References}

Barbieri, J. C., Vasconcelos, I. F. G., Andreassi, T., \& Vasconcelos, F. C. (2010). Inovação e sustentabilidade: Novos modelos e proposições. RAE-Revista de Administração de Empresas, 50(2), 146-154. https://doi.org/10.1590/s0034-75902010000200002

Baumgartner, R. J. (2011). Critical perspectives of sustainable development research and practice. Journal of Cleaner Production, 19(8), 783-786. https://doi.org/10.1016/j.jclepro.2011.01.005

Belk, R. (2010). Sharing. Journal of Consumer Research, 36(5), 715-734. https://doi.org/10.1086/612649

Bicicletar. (2014). Bem-vindo ao bicicletar e mini bicicletar. Retrieved August, 2016, from http://www.bicicletar.com.br/home.aspx

Botsman, R., \& Rogers, R. (2011). O que é meu é seu: Como o consumo colaborativo vai mudar o nosso mundo. Porto Alegre, RS: Bookman.

Carvalho, C. A., Andrade, J. A., \& Mariz, L. A. (2005). Mudança na teoria institucional. Anais do Encontro Nacional da Associação Nacional de Pós-graduação e Pesquisa em Administração, Brasília, DF, Brasil, 29.

Carvalho, C. A., Vieira, M. M. F, \& Lopes, F. D. (1999). Contribuições da perspectiva institucional. Encontro Nacional da Associação Nacional de Pós-graduação e Pesquisa em Administração, Foz do Iguaçu, PR, Brasil, 23. 
Cavalcante, E. D. C., \& Bispo, M. S. (2014). Sustentabilidade como prática: Um olhar etnometodológico e sociomaterial a partir da orla marítima de João Pessoa, Paraíba. Organizações $e$ Sustentabilidade, 2(2), 80-113. http://dx.doi.org/10.5433/2318-9223.2014v2n2p80

Chase, R. (2015). Economia compartilhada: Como pessoas e plataformas da Peers Inc. estão reinventando o capitalismo. São Paulo: HSM do Brasil.

Chauí, M. S. (2010). Convite à filosofia (14a ed.). São Paulo: Editora Ática.

Claro, P. B. O., Claro, D. P., \& Amâncio, R. (2008). Entendendo o conceito de sustentabilidade nas organizações. Revista de Administração da USP, 43(4), 289-300. Retrieved from http://200.232.30.99/busca/artigo.asp?num_artigo=1354

Cohen, B., \& Kietzmann, J. (2014). Ride on! Mobility business models for the sharing economy. Organization \& Environment, 27(3), 279-296. https://doi.org/10.1177/1086026614546199

Collis, J., \& Hussey, R. (2005). Pesquisa em administração: Um guia prático para alunos de graduação e pós-graduação. Porto Alegre, RS: Bookman.

Cruz, G. (2016). A criticism of the use of ideal types in studies on institutional logics. Organizações \& Sociedade, 23(79), 646-655. https://doi.org/10.1590/1984-9230711

DiMaggio, P. J., \& Powell, W. W. (1983). The iron cage revisited: Institutional isomorphism and collective rationality in organisational fields. American Sociological Review, 48(2), 147-160. https://doi.org/10.2307/2095101

Elkington, J. (2002). Cannibals with forks: The triple bottom line of 21 st century business. Oxford: Capstone.

Freitas, R. C. M., Nélsis, C. M., \& Nunes, L. S. (2012). A crítica marxista ao desenvolvimento (in)sustentável. Katálysis, 15(1), 41-51. https://doi.org/10.1590/s1414-49802012000100004

Frenken, K., \& Schor, J. (2017, June). Putting the sharing economy into perspective. Environmental Innovation and Societal Transitions, 23, 3-10. https://doi.org/10.1016/j.eist.2017.01.003

Friedland, R., \& Alford, R. R. (1991). Bringing society back it: Symbols, practices and institutional contradictions. In W. Powell \& P. DiMaggio (Eds.), The new institutionalism in organisational analysis (pp. 232-263). Chicago: University of Chicago Press.

Gansky, L. (2011). Mesh: Porque o futuro dos negócios é compartilhar. Rio de Janeiro: Alta Books Editora.

Gherardi, S. (2013). Prática? É uma questão de gosto! Revista Interdisciplinar de Gestão Social, 2(1), 107-124. Retrieved from https://portalseer.ufba.br/index.php/rigs/article/view/10047/7189

Godoy, A. S. (1995). A pesquisa qualitativa e sua utilização em Administração de Empresas. RAERevista de Administração de Empresas, 35(4), 65-71. https://doi.org/10.1590/s003475901995000400008

Godoy, A. S. (2006). Estudo de caso qualitativo. In A. Barbosa-da-Silva, C. K. Godoi, \& R. Bandeirade-Melo (Orgs.), Pesquisa qualitativa em estudos organizacionais: Paradigmas, estratégias e métodos (pp. 115-146). São Paulo: Saraiva.

Gomes, E. L. (2005). O desenvolvimento da lógica no Brasil: Da herança ibero-portuguesa aos primórdios do século XIX. Revista Eletrônica Informação e Cognição (Cessada), 4(1), 10-33. Retrieved from http://www2.marilia.unesp.br/revistas/index.php/reic/article/view/720/622 
Guarido, E. R., Filho, Machado-da-Silva, C. L., \& Gonçalves, S. A. (2009). Institucionalização da teoria institucional nos contextos dos estudos organizacionais no Brasil. Anais do Encontro Nacional da Associação Nacional de Pós-Graduação e Pesquisa em Administração, São Paulo, SP, Brasil, 33.

Heinrichs, H. (2013). Sharing economy: A potential new pathway to sustainability. Gaia - Ecological Perspectives for Science and Society, 22(4), 228-231. https://doi.org/10.14512/gaia.22.4.5

Iyer-Raniga, U., \& Treloar, G. (2000). FORUM: A context for participation in sustainable development. Environmental Management, 26(4), 349-361. https://doi.org/10.1007/s002670010092

Kanter, R. M. (2011). Grandes empresas pensam diferente. Harvard Business Review Brasil. Retrieved from http://hbrbr.com.br/grandes-empresas-pensam-diferente/

Lei n. 10.257, de 10 de julho de 2001. (2001). Regulamenta os arts. 182 e 183 da Constituição Federal, estabelece diretrizes gerais da política urbana e dá outras providências. Retrieved from http://www.planalto.gov.br/ccivil_03/leis/LEIS_2001/L10257.htm

Lei $n$. 12.587, de 3 de janeiro de 2012. (2012). Institui as diretrizes da Política Nacional de Mobilidade Urbana; revoga dispositivos dos Decretos-Leis nos 3.326, de 3 de junho de 1941, e 5.405, de 13 de abril de 1943, da Consolidação das Leis do Trabalho (CLT), aprovada pelo Decreto-Lei no 5.452, de 1o de maio de 1943, e das Leis nos 5.917, de 10 de setembro de 1973, e 6.261, de 14 de novembro de 1975; e dá outras providências. Retrieved from http://www.planalto.gov.br/ccivil_03/_ato2011-2014/2012/lei/112587.htm

Lei n. 10.303, de 23 de dezembro de 2014. (2014). Institui a política de transporte cicloviário, aprova o plano diretor cicloviário integrado do município de fortaleza, e dá outras providências. Retrieved October, 2016 from https://leismunicipais.com.br/a/ce/f/fortaleza/leiordinaria/2014/1031/10303/lei-ordinaria-n-10303-2014-institui-a-politica-de-transportecicloviario-aprova-o-plano-diretor-cicloviario-integrado-do-municipio-de-fortaleza-e-da-outrasprovidencias

Lounsbury, M. (2007). A tale of two cities: Competing logics and practice variation in the professionalizing of mutual fund. Academy of Management Journal, 50(2), 289-307. https://doi.org/10.5465/amj.2007.24634436

Martin, C. J. (2015). Initial steps towards a research agenda for the sharing economy and socio-technical transitions. Studies, 31, 1-6.

Martin, C. J. (2016). The sharing economy: A pathway to sustainability or a nightmarish form of neoliberal capitalism? Ecological Economics, 121, 149-159. https://doi.org/10.1016/j.ecolecon.2015.11.027

Meyer, J. W., \& Rowan, B. (1977). Institutionalized organizations: formal structure as myth and ceremony. American Journal of Sociology, 83(2), 340-363. https://doi.org/10.1086/226550

Minayo, M. C. S. (2011). Pesquisa social: Teoria, método e criatividade. Rio de Janeiro: Vozes Limitada.

Munk, L., Souza, R. B., \& Zagui, C. (2012). A gestão por competências e sua relação com ações voltadas à sustentabilidade. Revista de Gestão, 19(3), 371-389. https://doi.org/10.5700/rege469

Nicolini, D., Gherardi, S., \& Yanow, D. (2003). Introduction: Toward a practise-based view of knowing and learning in organizations. In D. Nicolini, S. Gherardi, \& D. Yanow (Eds.), Knowing in organizations: A practice-based approach (pp. 3-31). New York: M. E. Sharpe. 
Ornellas, R. (2013). Impactos do consumo colaborativo de veículos elétricos na cidade de São Paulo. Future Studies Research Journal, 5(1), 33-62. https://doi.org/10.7444/fsrj.v5i1.93

Ortner, S. B. (1984). Theory in anthropology since the sixties. Comparative Studies in Society and History, 26(1), 126-166. https://doi.org/10.1017/s0010417500010811

Petrini, M., Freitas, C. S., \& Silveira, L. M. (2017). A proposal for a typology of sharing economy. Revista de Administração Mackenzie, 18(5), 39-62. https://doi.org/10.1590/167869712017/administracao.v18n5p39-62

Prefeitura de Fortaleza. (2014, December 15). Prefeitura inaugura sistema de bicicletas compartilhadas com 15 estações instaladas. Retrieved from https://www.fortaleza.ce.gov.br/noticias/prefeiturade-fortaleza-inaugura-sistema-de-bicicletas-compartilhadas-com-15

Prefeitura de Fortaleza. (2015, November 20). Prefeitura entrega mais duas estações do Bicicletar e conclui etapa de implementação do sistema. Retrieved from https://www.fortaleza.ce.gov.br/noticias/prefeitura-entrega-mais-duas-estacoes-do-bicicletar-econclui-etapa-de

Rifkin, J. (2016). Sociedade com custo marginal zero. São Paulo: M. Books.

Silva, M. E., \& Figueiredo, M. D. (2017). Sustainability as practice: Reflections on the creation of an institutional logic. Sustainability, 9(10), 1839. https://doi.org/10.3390/su9101839

Silveira, L. M., Petrini, M., \& Santos, A. C. M. Z. (2016). Economia compartilhada e consumo colaborativo: O que estamos pesquisando?. REGE-Revista de Gestão, 23(4), 298-305. https://doi.org/10.1016/j.rege.2016.09.005

Sistema de bicicletas compartilhadas de Fortaleza contará com 15 estações até novembro. (2014, $\begin{array}{lllll}\text { October 20). } & O & \text { Povo. } & \text { Retrieved }\end{array}$ https://www20.opovo.com.br/app/fortaleza/2014/10/20/noticiafortaleza,3334271/sistema-debicicletas-compartilhadas-de-fortaleza-contara-com-15-estac.shtml

Souza-Silva, J. C., \& Davel, E. (2007). Da ação à colaboração reflexiva em comunidades de prática. RAE-Revista de Administração de Empresas, 47(3), 53-65. https://doi.org/10.1590/s003475902007000300005

Thornton, P. H. (2002). The rise of the corporation in a craft industry: Conflict and conformity in institutional logics. Academy of Management Journal, 45(1), 81-101. https://doi.org/10.5465/3069286

Thornton, P. H., Jones, C., \& Kury, K. (2005). Institutional logics and institutional change in organizations: Transformation in accounting, architecture, and publishing. In C. Jones \& P. H. Thornton (Eds.), Research in the sociology of organizations (pp. 125-170). Greenwich, CT: JAI Press Inc.

Thornton, P. H., \& Ocasio, W. (1999). Institutional logics and the historical contingency of power in organizations: Executive succession in the higher education publishing industry, 1958-1990. American Journal of Sociology, 105(3), 801-843. https://doi.org/10.1086/210361

Thornton, P. H., \& Ocasio, W. (2008). Institutional logics. In R. Greenwood, C. Oliver, K. Sahlin, \& R. Suddaby (Eds.), The SAGE Handbook of Organisational Institutionalism (pp. 99-129). Thousand Oaks, CA: Sage Publications.

Thornton, P. H., Ocasio, W., \& Lounsbury, M. (2012). The institutional logics perspective: A new approach to culture, structure and process. Oxford: Oxford University Press. 
Vaskelainen, T., \& Münzel, K. (in press). The effect of institutional logics on business model development in the sharing economy: The case of German carsharing services. Academy of Management Discoveries. https://doi.org/10.5465/amd.2016.0149

Yin, R. K. (2014). Case study research: Design and methods (5th ed.). Thousand Oaks, CA: Sage Publications.

\section{Authors}

Suzenny T. Rechene

BR 155, KM 25, Assentamento 26 de Março, Caixa Postal 41, 68508-970, Marabá, PA, Brazil. E-mail address: srechene@hotmail.com. https://orcid.org/0000-0001-9665-9034

Minelle E. Silva

Av. Washintong Soares, 1321, Edson Queiroz, Bloco E, Sala 13, 60811-905, Fortaleza, CE, Brazil. E-mail address: minele.adm@gmail.com. https://orcid.org/0000-0003-2074-6478

Simone A. P. Campos

Av. Roraima, 1000, Prédio 7, Camobi, 97105-900, Santa Maria, RS, Brazil. E-mail address: simoneapcampos@gmail.com. https://orcid.org/0000-0001-9627-7677 